\title{
Peningkatan Kemampuan Menulis Melalui Metode Bermain Jawaban Dalam Pembelajaran Bahasa Indonesia Kelas III SDN 06 Kampung Baru Pariaman
}

\section{Ernita}

\begin{abstract}
This research is based one fact that the writing skill of student in learning Bahasa was still low.it was caused by method "speech" that teacher used to implement. This research is aimed to improve student's writing skill by implementing playing-answer method in learning Bahasa. This is class action research whose subject were students grade III in SDN 06 Kampung Baru. Data were obtained through observation sheet and final test. The result shows that average score of students improves from 68.00 inc cycle I to 77.05 in cycle II. Then, percentage of successful students improves from $55 \%$ in cycle I to $80 \%$ in cycle II. Thus, it can be concluded that implementation of playing-answer method in learning Bahasa can improve student's writing skill.
\end{abstract}

Keyword: playing-answer method, writing skill

Copyright (C) 2016 IICET (Padang - Indonesia) - All Rights Reserved Indonesian Institute for Counseling, Education and Theraphy (IICET)

\section{PENDAHULUAN}

Pembelajaran Bahasa Indonesia terdiri atas empat aspek keterampilan yaitu menyimak, berbicara, membaca dan menulis. Salah satu bidang aktivitas dan materi pengajaran bahasa Indonesia di Sekolah Dasar yang memegang peranan penting ialah pengajaran menulis. Untuk menghasilkan tulisan yang baik setiap orang diharuskan memiliki keterampilan menulis. Keterampilan menulis akan tercipta dengan sendirinya apabila diiringi dengan hobi dan latihan yang terus menerus, karena menulis merupakan keterampilan berbahasa yang harus dikuasai dengan baik oleh siswa.

Dengan menulis seseorang dapat mengungkapkan perasaan, ide, dan gagasan. Proses menulis adalah kegiatan penulis dalam menghasilkan suatu tulisan. Kegiatan tersebut diawali dengan memilih, memilah dan menyusun tulisan, menuliskan pesan dalam bahasa tulis, dan menyerpunakan (merevisi) tulisan sebelum disampaikan kepada orang lain (pembaca). Penulis melaksanakan kegiatan tersebut secara bertahap dan berlanjut ulang. Selain penulis mengunakan pengetahuan dan pengalaman (skemata), penulis harus mampu menggunakan unsur retorika berbahasa dan penalaran dalam proses menulis.

Susanto (2006: 240-242) mengutip buku Resmini mengungkapkan "pembelajaran menulis di SD dibedakan menjadi dua, yaitu menulis permulaan dan menulis lanjutan'. Pembelajarn menulis lanjutan disebut juga mengarang seperti mengarang deskripsi. Karangan deskripsi adalah karangan yang memaparkan suatu hal, peristiwa/kejadian seperti apa adanya.

Dari hasil wawancara peneliti dengan guru kelas III diketahui bahwa hasil belajar mengarang siswa pada semester 1 tahun ajaran 2014-2015 masih rendah. Dari 20 siswa di kelas terdapat 12 orang siswa lakilaki dan 8 orang siswa perempuan. Siswa laki-laki yang mendapat nilai di atas 70 sebanyak 6 orang dan yang mendapat nilai di bawah 70 sebanyak 6 orang, sedangkan siswa perempuan yang mendapat nilai di atas 70 sebanyak 6 orang dan yang mendapat nilai di bawah 70 seabnyak 2 orang. Jadi siswa yang mendapat nilai di atas 70 sebanyak 12 orang dan nilai di bawah 70 sebanyak 8 orang. Sedangkan Kriteria Ketuntasan Minimal (KKM) adalah 70. Hal ini membuktikan bahwa kurangnya kemampuan siswa dalam menulis suatu karangan yang ditandai dengan rendahnya nilai karangan siswa.

Dalam meningkatkan kemampuan menulis melalui metode bermain jawaban siswa SD tersebut diperlukan latihan dan kebiasaan menulis yang sesuai dengan pembelajaran. Menurut Susanto (2012: 249) "Menulis adalah kegiatan seseorang menempatkan sesuatu pada sebuah dimensi ruang yang masih kosong, setelah itu hasilnya yang berbentuk tulisan dapat dibaca dan dipahami isinya". Keterampilan menulis dapat membantu kita menyerap dan menguasai informasi serta menghasilkan ide-ide baru yang dapat digunakan sebagai sumber belajar. Dengan mengetahui dan mengikuti langkah-langkah yang jelas siswa diharapkan menghasilkan penulisan yang baik dan benar. 
Menurut Zaini, dkk (2005: 87-88) metode bermain jawaban adalah sebuah permainan yang dapat melibatkan semua siswa dari menit-menit awal sampai akhir. Dalam permaianan ini, siswa ditantang untuk mencari jawaban yang benar dan sekaligus bergantung pada faktor keberuntungan. Permainan ini dapat digunakan untuk pretest maupun post-test, disamping tentunya untuk mengajarkan materi yang baru. Dalam permainan ini, guru mengajar dengan menggunakan jawaban-jawaban yang ditemukan oleh siswa.

Berdasarkan uraian di atas, maka peneliti melakukan penelitian tindakan kelas melalui implementasi metode bermain jawaban dalam pembelajaran Bahasa Indonesia. Tujuan penelitian tindakan kelas ini adalah untuk meningkatkan kemampuan pembelajaran menulis melalui metode bermain jawaban di kelas III SDN 06 Kampung Baru Kecamatan Pariaman Timur Kota Pariaman.

\section{METODOLOGI PENELITIAN}

Penelitian tindakan kelas ini dilakukan di SD 06 Kampung Baru Kecamatan Pariaman Timur Kota Pariaman, dengan mempertimbangkan bahwa sekolah tersebut mau menerima inovasi pendidikan terutama dalam proses pembelajaran untuk peningkatan kemampuan menulis siswa pada pembelajaran Bahasa Indonesia. Subjek dalam penelitian ini adalah siswa kelas III di SD 06 Kampung Baru Kecamatan Pariaman Timur Kota Pariaman yang berjumlah 20 orang, yang terdiri dari 12 laki-laki dan 8 perempuan. Dalam penelitian ini, peneliti menggunakan beberapa instrumen yang digunakan untuk mengumpulkan data, yaitu:

1. Lembar Pelaksanaan Pembelajaran Guru

Dalam lembar observasi ini, observer mengamati setiap aktivitas yang dilakukan oleh guru saat kegiatan pembelajaran berlangsung. Mulai dari appersepsi, kegiatan inti, pengelolaan kelas, hingga kegiatan penutup. Observer akan mengamati apakah guru telah mengajar sesuai dengan RPP yang telah dibuat sebelumnya. Kegiatan pelaksanaan pembelajaran di amati oleh obsever.

2. Lembar Observasi Kemampuan Menulis Siswa

Lembar observasi belajar siswa berisi penilaian terhadap kemampuan menulis siswa seperti mengajukan pertanyaan, menjawab pertanyaan dan berdiskusi. Kemampuan menulis siswa ini diamati oleh Observer .

3. Tes Hasil Belajar

Tes hasil belajar digunakan untuk mendapatkan data hasil belajar siswa pada setiap siklus tindakan. Tes berisi soal-soal tentang materi yang telah dipelajari. Soal-soal ini dirumuskan berdasarkan indikator pembelajaran. Tes hasil belajar ini dilakukan secara tertulis terdiri dari soal yang berbentuk karangan bergambar dimana siswa mampu menulis dan mengarang dengan menggunakan tulisan serta kalimat sesuai EYD.

Data yang diperoleh kemudian dianalisis dengan menggunakan pendekatan kualitatif dan kuatitatif karena peneliti ingin mengamati fenomena yang terjadi di dalam kelas. Indikator keberhasilan pada penelitian ini adalah apabila siswa mendapatkan nilai 70 atau lebih, sesuai dengan standar KKM. Siswa dikatakan tuntas belajar apabila telah mencapai acuan standar Kriteria Ketuntasan Minimal (KKM) yang ditetapkan oleh sekolah tempat penelitian yaitu 70. Sedangkan indikator pada kemampuan menulis siswa adalah:

1. Siswa dalam menulis menggunakan EYD meningkat menjadi $70 \%$.

2. Siswa dalam menulis menggunakan huruf kapital meningkat menjadi $70 \%$.

\section{HASIL DAN PEMBAHASAN PENELITIAN}

\section{A. Hasil Penelitian \\ 1. Siklus I \\ a) Tahap Perencanaan}

Sebelum menerapkan tindakan pada siklus I, guru melihat terlebih dahulu kondisi pembelajaran Bahasa Indonesia pada siswa kelas III SD Negeri 06 Kampung Baru Kecamatan Pariaman Timur Kota Pariaman. Tindakan ini digunakan untuk melihat kondisi awal, sehingga dapat dijadikan patokan terhadap adanya peningkatan kemampuan menulis siswa setelah dilakukan tindakan. Selanjutnya untuk memulai pelajaran, terlebih dahulu peneiliti menyiapkan rencana pelaksanaan pelajaran (RPP), lembar observasi kegiatan siswa, lembar observasi kegiatan guru, soal latihan dan lembar jawaban yang sesuai dengan metode yang dipakai peneliti.

\section{b) Tahap Pelaksanaan}

Pelaksanaan pembelajaran pada siklus I, dengan menggunakan model bermain jawaban dikelas III SD Negeri 06 Kampung Baru Kecamatan Pariaman Timur Kota Pariaman. Pembelajaran ini dilaksanakan 2 x pertemuan pada siklus I.

\section{c) Tahap Pengamatan}

Pengamatan pada siklus pertama ini dilaksanan pada waktu proses pembelajaran Bahasa Indonesia dengan menggunakan model bermain jawaban. Pengamatan juga dilakukan pada Siswa dan guru. Pada 
penelitian ini peneliti juga diamati oleh observer yaitu guru kelas III. Dalam kegiatan ini observer bekerja mengamati Siswa dan guru dalam porses pembelajaran, dengan cara memberi ceklis pada lembaran observasi yang telah disediakan sebelumnya. Hasil dari pengamatan ini direflesikan untuk perencanaan tindakan berikutnya. Adapun pengamatan observer adalah sebagai berikut:

\section{a. Data Hasil Observasi kegiatan Guru}

Berdasarkan lembar observasi pelaksanaan proses pembelajaran guru dalam pembelajaran pada siklus I, maka jumlah skor dan persentase kegiatan guru dalam mengelola pembelajaran pada siklus I dapat dilihat pada Tabel 1 berikut:

\section{Tabel 1}

Persentase Kegiatan Guru Pada Siklus I

\begin{tabular}{ccc}
\hline Pertemuan & Jumlah Skor & Persentase \\
\hline $\mathbf{1}$ & 28 & $51,85 \%$ \\
$\mathbf{2}$ & 35 & $64,81 \%$ \\
\multicolumn{2}{c}{ Rata-rata } & $58,33 \%$ \\
\hline
\end{tabular}

Berdasarkan Tabel 1 tersebut, maka persentase kegiatan guru pada siklus I dikategorikan cukup.

b. Hasil Observasi Kegiatan Siswa

Hasil observasi terhadap kegiatan siswa dapat dilihat pada Tabel 2 berikut.

Tabel 2

Persentase Kegiatan Siswa Pada Siklus I

\begin{tabular}{|c|c|c|c|c|c|}
\hline \multirow[t]{3}{*}{ Indikator } & \multicolumn{4}{|c|}{ Skor Pertemuan Ke } & \multirow[t]{3}{*}{ Rata-rata Persentase } \\
\hline & \multicolumn{2}{|c|}{1} & \multicolumn{2}{|c|}{2} & \\
\hline & Jumlah & $\%$ & Jumlah & $\%$ & \\
\hline Diskusi & 6 & 30,00 & 9 & 45,00 & 37,05 \\
\hline Menjawab & 5 & 25,00 & 9 & 45,00 & 35,00 \\
\hline Menanggapi & 6 & 30,00 & 8 & 40,00 & 35,00 \\
\hline Mengikuti Dikusi Yang Baik & 7 & 35,00 & 10 & 50,00 & 42,05 \\
\hline Rata-rata & 6 & 30,00 & 9 & 45,75 & 37,05 \\
\hline
\end{tabular}

Berdasarkan Tabel 2 tersebut diketahui bahwa:

1. Siswa yang berdiskusi pada pertemuan 1 berjumlah 6 orang dengan persentase $30,00 \%$, sedangkan pada pertemuan 2 siklus I siswa yang berdiskusi berjumlah 9 orang dengan persentase 45,00\%. Sehingga diperoleh rata-rata persentase 37,05\% dalam kategori kurang.

2. Siswa yang menjawab pertanyaan pada pertemuan 1 berjumlah 5 orang dengan persentase $25,00 \%$, sedangkan pada pertemuan 2 siswa menjawab pertanyaan berjumlah 9 orang dengan persentase $45,00 \%$. Sehingga diperoleh rata-rata persentase $35,00 \%$ dalam kategori kurang.

3. Siswa yang menanggapi pada pertemuan 1 siklus I berjumlah 6 orang dengan persentase 30,00\%, sedangkan pada pertemuan 2 siklus I siswa yang menanggapi berjumlah 8 orang dengan persentase $40,00 \%$. Sehingga diperoleh rata-rata persentase 35,00\% dalam kategori kurang.

4. Siswa yang mengikuti diskusi dengan baik pada pertemuan 1 siklus I berjumlah 7 orang dengan persentase $35,00 \%$, sedangkan pada pertemuan 2 siklus I siswa yang mengikuti diskusi yang baik berjumlah 10 orang dengan persentase $50,00 \%$. Sehingga diperoleh rata-rata persentase $42,05 \%$ dalam kategori kurang.

Dari data hasil penelitian di siklus I di atas dapat disimpulkan bahwa guru harus lebih meningkatkan motivasi belajar siswa sehinggga siswa lebih termotivasi dalam pembelajaran Bahasa Indonesia.

\section{Data Hasil Belajar}

Berdasarkan hasil tes siklus I terkait tes akhir, persentase siswa yang tuntas tes akhir siklus dan rata-rata skor tesnya dapat dilihat pada Tabel 3 berikut: 
Tabel 3 Ketuntasan dan Rata-rata Hasil

Belajar Menulis Siswa Pada Siklus I

\begin{tabular}{ccc}
\hline Uraian & Nilai & Target \\
\hline Jumlah siswa yang mengikuti tes & 20 & - \\
Jumlah siswa yang tuntas & 11 & - \\
Jumlah siswa yang tidak tuntas & 9 & - \\
Persentase ketuntasan belajar siswa & $55,00 \%$ & $70 \%$ \\
Rata-rata skor siswa & 68 & 70 \\
\hline
\end{tabular}

Dari tabel di atas dapat dilihat bahwa hasil belajar menulis siswa pada tes akhir siklus I siswa yang mengikuti tes hasil belajar adalah 20 orang. Sedangkan siswa yang tuntas dalam tes adalah 11 orang dan yang tidak tuntas adalah 9 orang. Persentase ketuntasan hasil belajar adalah 55,00\%, sedangkan target ketuntasan hasil belajar adalah $70 \%$.

\section{d) Tahap Refleksi}

Kegiatan refleksi dilakukan antara peneliti dan kepala sekolah yang dilakukan pada setiap siklus berakhir. Refleksi siklus I ini mencakup refleksi terhadap perencanaan, pelaksanaan, kegiatan, dan hasil yang diperoleh oleh siswa. Dari tahap perencanaan, peneliti mempersiapkan RPP, lembar observasi kegiatan siswa, observasi guru, tes hasil belajar menulis. Dalam tahap ini, peneliti belum mempersiapkan perencanaan dengan maksimal.

Dari pelaksanaan tindakan dan observasi pada siklus I ini, tampak bahwa rata-rata persentase hasil belajar dalam menulis 55\%. Jadi, rata-rata persentase kemampuan menulis siswa siklus I masih dikatakan sedikit, belum mencapai target yang ditetapkan yaitu $70 \%$. Berdasarkan temuan di atas, peneliti mengidentifikasi beberapa penyebab terjadinya masalah tersebut sebagai berikut:

1) Guru kurang memahami metode bermain jawaban

2) Siswa belum terbiasa dengan metode bermain jawaban

Permasalahan di atas berdampak pada kurang maksimalnya hasil belajar dan peneliti memutuskan untuk melanjutkan penelitian pada siklus II. Adapun yang dapat dilakukan guru untuk meningkatkan kemampuan belajar menulis siswa pada siklus II adalah:

1) Guru harus lebih memahami metode bermain jawaban

2) Guru harus meningkatkan kreatifitas siswa, agar siswa aktif dalam proses pembelajaran

\section{Siklus II}

a) Tahap Perencanaan

Sebelum menerapkan tindakan pada siklus II, guru melihat terlebih dahulu kondisi pembelajaran Bahasa Indonesia pada siswa kelas III SD Negeri 06 Kampung Baru Kecamatan Pariaman Timur Kota Pariaman. Tindakan ini digunakan untuk melihat kondisi awal pada siklus I, sehingga dapat dijadikan patokan terhadap adanya peningkatan kemampuan menulis siswa setelah dilakukan tindakan siklus II. Selanjutnya untuk memulai pelajaran, terlebih dahulu peneiliti menyiapkan rencana pelaksanaan pelajaran (RPP), lembar observasi kegiatan siswa, lembar observasi kegiatan guru, soal latihan menulis yang sesuai dengan metode yang dipakai peneliti.

b) Tahap Pelaksanaan

Pelaksanaan pembelajaran pada siklus II, dengan menggunakan metode bermain jawaban dikelas III SD Negeri 06 Kampung Baru Kecamatan Pariaman Timur Kota Pariaman. Pembelajaran ini dilaksanakan 2 x pertemuan pada siklus II.

c) Tahap Pengamatan

Pengamatan pada siklus kedua ini dilaksanakan pada waktu proses pembelajaran Bahasa Indonesia dengan menggunakan model bermain jawaban. Pengamatan juga dilakukan pada Siswa dan guru. Pada penelitian ini peneliti juga diamati oleh observer yaitu, guru kelas III. Dalam kegiatan ini observer bekerja mengamati Siswa dan guru dalam porses pembelajaran, dengan cara memberi ceklis pada lembaran observasi yang telah disediakan sebelumnya. Hasil dari pengamatan ini direflesikan untuk perencanaan tindakan berikutnya. Adapun pengamatan observer adalah sebagai berikut:

\section{a. Data Hasil Observasi Kegiatan Guru}

Berdasarkan lembar observasi pelakasanaan proses pembelajaran guru dalam pembelajaran pada siklus I, maka jumlah skor dan persentase pelakasanaan proses pembelajaran guru dalam mengelola pembelajaran pada siklus I dapat dilihat pada Tabel 4 berikut: 


\section{Tabel 4}

Persentase Kegiatan Guru Pada Siklus Kedua

\begin{tabular}{ccc}
\hline \multirow{2}{*}{ Pertemuan } & Jumlah Skor & Persentase \\
\hline $\mathbf{1}$ & 41 & $75,92 \%$ \\
$\mathbf{2}$ & 48 & $88,88 \%$ \\
\multicolumn{2}{c}{ Rata-rata } & $82,04 \%$ \\
\hline
\end{tabular}

Pada Tabel 4 tersebut diperoleh fakta bahwa dalam model bermain jawaban dalam pembelajaran Bahasa Indonesia pada siklus kedua persentase $75,92 \%$ dan pertemuan kedua $88,88 \%$. Dapat disimpulkan kalau kriteria dalam pengamatan pelakasanaan proses pembelajaran guru mendapatkan nilai sangat baik

\section{b. Hasil Observasi Kegiatan Siswa}

Data hasil observasi yang didapat menggunakan lembar observasi kegiatan siswa. Digunakan untuk melihat proses dan perkembangan keaktifan yang terjadi selama pembelajaran. Hasil observasi observer terhadap keaktifan siswa dapat dilihat dalam pembelajaran pada Tabel 5 berikut:

\section{Tabel 5}

Persentase Kegiatan Siswa Pada Siklus II

\begin{tabular}{|c|c|c|c|c|c|}
\hline \multirow{3}{*}{ Indikator } & \multicolumn{4}{|c|}{ Pertemuan Ke } & \multirow{3}{*}{ Rata-rata Persentase } \\
\hline & \multicolumn{2}{|c|}{1} & \multicolumn{2}{|l|}{2} & \\
\hline & Jumlah & $\%$ & Jumlah & $\%$ & \\
\hline Diskusi & 13 & 65,00 & 15 & 75,00 & 70,00 \\
\hline Menjawab & 13 & 65,00 & 14 & 70,00 & 67,05 \\
\hline Menanggapi & 12 & 60,00 & 16 & 80,00 & 70,00 \\
\hline Mengikuti diskusi dengan baik & 14 & 70,00 & 17 & 85,00 & 77,05 \\
\hline Rata-rata & 13 & 65 & 62 & 77,05 & 71,25 \\
\hline
\end{tabular}

Berdasarkan Tabel 5 tersebut dapat dilihat bahwa kegiatan siswa pada siklus II sudah meningkat terlihat pada persentase yang ditetapkan guru sebanyak $70 \%$. Sedangkan hasil siklus II pertemuan I rata-rata persentase diskusi siswa hanya 65\%, menjawab $65 \%$, serta menanggapi pertanyaan $60 \%$ dan mengikuti diskusi dengan baik $70 \%$. Sedangkan pertemuan II rata-rata persentase diskusi siswa hanya $75 \%$, menjawab $70 \%$, dan menanggapi $80 \%$ dan mengikuti diskusi dengan baik $85 \%$. hal ini dapat di jelaskan sebagai berikut:

1. Siswa yang berdikusi pada pertemuan 1 berjumlah 13 orang dengan persentase $65,00 \%$, sedangkan pada pertemuan 2 siklus I siswa yang bertanya berjumlah 15 orang dengan persentase 75,00\%. Sehingga diperoleh rata-rata persentase 70,00\% dalam kategori baik.

2. Siswa yang menjawab pertanyaan pada pertemuan 1 berjumlah 13 orang dengan persentase $65,00 \%$, sedangkan pada pertemuan 2 siswa menjawab pertanyaan berjumlah 14 orang dengan persentase $70,00 \%$. Sehingga diperoleh rata-rata persentase $67,05 \%$ dalam kategori baik.

3. Siswa yang menanggapi pada pertemuan 1 siklus I berjumlah 12 orang dengan persentase $60,00 \%$, sedangkan pada pertemuan 2 siklus I siswa yang menanggapi berjumlah 16 orang dengan persentase $80,00 \%$. Sehingga diperoleh rata-rata persentase $70,00 \%$ dalam kategori baik.

4. Siswa yang mengikuti diskusi dengan baik pada pertemuan 1 siklus I berjumlah 14 orang dengan persentase $70,00 \%$, sedangkan pada pertemuan 2 siklus I siswa yang mengikuti diskusi dengan baik berjumlah 17 orang dengan persentase $85,00 \%$. Sehingga diperoleh rata-rata persentase $77,05 \%$ dalam kategori baik

Berdasarkan hasil data observasi di atas dapat disimpulkan pada siklus II pada pertemuan I dan pertemuan II bahwa guru telah mampu meningkatkan kegiatan siswa, sehinggga siswa lebih aktif dalam pembelajaran Bahasa Indonesia.

\section{c. Data Hasil Belajar}

Berdasarkan hasil tes siklus II tersebut persentase siswa yang tuntas tes akhir siklus dan rata-rata skor tesnya dapat dilihat pada Tabel 6 berikut: 
Tabel 6

Ketuntasan dan Rata-rata Hasil Belajar Menulis Siswa Pada Siklus II

\begin{tabular}{ccc}
\hline Uraian & Nilai & Target \\
\hline Jumlah siswa yang mengikuti tes & 20 & - \\
\hline Jumlah siswa yang tuntas & 16 & - \\
Jumlah siswa yang tidak tuntas & 4 & - \\
Persentase ketuntasan belajar siswa & $80,00 \%$ & $70 \%$ \\
\hline Rata-rata skor siswa & 77,5 & 70 \\
\hline
\end{tabular}

Dari analisis data tersebut dapat dilihat bahwa hasil belajar siswa pada tes akhir siklus II siswa yang mengikuti tes hasil belajar menulis adalah 20 orang. Sedangkan siswa yang tuntas dalam tes adalah 16 orang dan yang tidak tuntas adalah 4 orang. Persentase ketuntasan hasil belajar menulis adalah $80,00 \%$, sedangkan target ketuntasan hasil belajar adalah $70 \%$.

d) Tahap Refleksi

Kegiatan refleksi dilakukan secara kolaboratif antara peneliti dengan observer pada setiap pembelajaran berakhir. Pada kesempatan ini temuan dan hasil pengamatan peneliti dibahas bersama. Refleksi tindakan siklus II ini mencakup refleksi terhadap perencanaan, pelaksanaan, pengamatan, dan hasil menulis yang diperoleh oleh siswa. Dilihat dari data hasil tes siklus II siswa, maka sudah mencapai target yang ditetapkan dan keberhasilan belajar menulis sangat baik mengunakan metode bermain jawaban. Sedangkan data pengamatan kegiatan guru dalam mengelola pelajaran sudah mengalami peningkatan dibandingkan pada siklus I, dan dapat dikatakan cukup baik.

Berdasarkan analisis data yang telah diuraikan di atas, maka disimpulkan bahwa peningkatan kemampuan menulis melalui metode bermain jawaban dalam pembelajaran bahasa Indonesia kelas III SD 06 Kampung Baru Kecamatan Pariaman Timur Kota Pariaman pada siklus II sudah meningkat, dan karena itu diputuskan untuk tidak melanjutkan penelitian pada siklus berikutnya. Dengan demikian penelitian ini telah selesai.

\section{B. Pembahasan}

Penelitian tindakan kelas ini terdiri dari dua siklus yang setiap siklusnya terdiri dari 2 kali pertemuan dan 1 kali tes hasil belajar pada akhir siklus. Pelaksanaan pembelajaran yang dilaksanakan menggunakan model pembelajaran bermain jawaban. Penelitian ini menggunakan instrumen penelitian berupa lembar observasi kegiatan belajar siswa, lembar observasi kegiatan guru, serta tes hasil belajar menulis. Melalui metode bermaian jawaban merupakan hal yang baru bagi siswa sehingga dalam pelaksanaannya peneliti menemui berbagai kendala.

Berdasarkan gambaran serta penjelasan tentang metode pembelajaran bermain jawaban di atas, peneliti memulai penelitian dengan merancang beberapa tahapan, dimulai perencanaan yaitu mengkaji silabus mata pelajaran Bahasa Indonesia kelas III semester genap, kemudian peneliti menyiapkan perangkat pembelajaran (RPP). Selanjutnya, peneliti memilih buku pegangan yaitu buku paket Bahasa Indonesia penerbit Erlangga untuk SD kelas III. Lalu, peneliti menyiapkan media pembelajaran, menyusun lembar observasi kegiatan siswa, menyusun lembar observasi kegiatan guru, dan menyusun tes hasil belajar menulis siswa. Selanjutnya, pada proses pelaksanaan pembelajaran yang dimulai dari kegiatan awal berisi berdo'a, apersepsi dan kemampuan menulis, kegiatan inti berisi menyampaikan materi pelajaran, pembelajaran menggunakan metode pembelajaran bermain jawaban dan cara guru dalam melaksanakan proses pembelajaran yaitu eksplorasi, elaborasi, dan konfirmasi. Kemudian, pada kegiatan akhir pembelajaran, berisi evaluasi dan untuk memperkuat data kejelasan peningkatan tersebut maka diadakan tes hasil belajar menulis yang di sini peneliti gunakan adalah berupa soal tes menulis. Untuk lebih rincinya dapat dilihat pada penjelasan dibawah ini:

\section{Pelaksanaan Kegiatan Guru}

Keberhasilan siswa dalam pembelajaran pada umumnya dilihat juga dari pengelolaan pelaksanaan pembelajaran pada persentase kegiatan guru. Dalam hal ini terlihat peningkatan pengelolaan pelaksanaan pembelajaran melalui metode pembelajaran bermain jawaban pada tabel di bawah ini: 


\section{Tabel 7}

Persentase Pelaksanaan Pembelajaran oleh Guru Melalui Metode Bermain Jawaban Pada Siklus I dan Siklus II

\begin{tabular}{cccc}
\hline \multirow{2}{*}{ Pertemuan } & \multicolumn{2}{c}{ Siklus } \\
\cline { 3 - 4 } & $\mathbf{1}$ & I & II \\
$\mathbf{2}$ & $51,85 \%$ & $75,92 \%$ \\
Rata-rata & $64,81 \%$ & $88,88 \%$ \\
\hline
\end{tabular}

Dari Tabel 7 tersebut dapat disimpulkan bahwa pelaksanaan pembelajaran melalui metode bermain jawaban dapat meningkatkan pelaksanaan pembelajaran kegiatan guru. Hal ini terlihat adanya peningkatan rata-rata persentase pelaksanaan pembelajaran oleh guru dari siklus I ke siklus II yaitu dari 58,33\% menjadi $81,46 \%$. Peningkatan pelaksanaan pembelajaran oleh guru disebabkan guru sudah bisa melaksanakan pembelajaran Bahasa Indonesia melalui metode bermain jawaban. Tantangan yang dihadapi guru selama proses pembelajaran salah satunya adalah guru belum terbiasa menggunakan model pembelajaran bermain jawaban dan juga guru belum mengenal karakter masing-masing siswa sehingga guru kadang-kadang salah menyikapi reaksi siswa.

\section{Kegiatan Siswa}

Kegiatan dari seseorang siswa dalam belajar adalah hal yang paling utama dalam pembelajaran. Kaktifan juga memiliki peranan sangat penting untuk mencapai keberhasilan dalam belajar menulis, karena dengan adanya kemampuan menulis yang baik dalam proses pembelajaran, siswa mudah memahami apa yang mereka tulis dalam buku setelah pembelajaran selesai, sehingga bisa mencapai hasil belajar menulis yang baik. Dengan meningkatnya keaktifan siswa dalam pembelajaran Bahasa Indonesi, diharapkan juga dapat meningkatkan hasil belajar menulis yang dilakukan dalam pembelajaran Bahasa Indonesia. Dalam penelitian ini, indikator kemampuan menulis siswa yang diukur dengan menggunakan model pembelajaran bermain jawaban adalah mampu aktif dalam berdiskusi, mampu aktif menjawab pertanyaan serta mampu menanggapi pertanyaan dan melihat siapa siswa yang mengikuti diskusi dengan baik. Untuk lebih jelasnya, dapat dilihat pada tabel di bawah ini:

Tabel 8

Persentase Rata-rata Kegiatan Siswa pada Siklus I dan Siklus II

\begin{tabular}{|c|c|c|c|}
\hline \multirow{2}{*}{$\mathrm{NO}$} & \multirow{2}{*}{ Indikator Kegiatan Siswa } & \multicolumn{2}{|c|}{ Rata-rata Persentase } \\
\hline & & Siklus I & Siklus II \\
\hline 1. & Siswa berdikusi & $37,05 \%$ & $70,00 \%$ \\
\hline 2. & Siswa menjawab pertanyaan & $35,00 \%$ & $67,05 \%$ \\
\hline 3. & Siswa bertanya & $35,00 \%$ & $70,00 \%$ \\
\hline 4. & Siswa mengikuti diskusi dengan baik & $42,05 \%$ & $77,05 \% ?$ \\
\hline & Rata-rata kedua siklus & $37,05 \%$ & $71,25 \%$ \\
\hline
\end{tabular}

Berdasarkan Tabel 8 tersebut dengan menggunakan rumus dapat disimpulkan bahwa pembelajaran Bahasa Indonesia menggunakan metode bermain jawaban yang dilaksanakan dapat terjadi peningkatan keaktifan siswa. Hal ini terbukti dari kenaikan rata-rata persentase untuk masing-masing indikator keberhasilan siswa yang telah ditetapkan, seperti:

1. Siswa yang berdiskusi pada siklus 1 dengan persentase $37,05 \%$, sedangkan pada siklus II siswa yang bertanya berjumlah dengan persentase $70,00 \%$. Sehingga dalam kategori baik.

2. Siswa yang menjawab pertanyaan pada siklus 1 dengan persentase $35,00 \%$, sedangkan pada siklus II siswa yang menjawab pertanyaan berjumlah dengan persentase $67,05 \%$. Sehingga dalam kategori baik.

3. Siswa yang menanggapi pada siklus 1 dengan persentase $35,00 \%$, sedangkan pada siklus II siswa yang menanggapi berjumlah dengan persentase $70,00 \%$. Sehingga dalam kategori baik.

4. Siswa yang mengikuti diskusi dengan baik pada siklus 1 dengan persentase $42,05 \%$, sedangkan pada siklus II siswa yang mengikuti diskusi dengan baik berjumlah dengan persentase $77,05 \%$. Sehingga dalam kategori baik 


\section{Hasil Belajar Menulis}

Berdasarkan hasil ulangan siswa yang dilakukan pada setiap akhir siklus, hasil belajar menulis siswa mengalami peningkatan yang cukup baik. Peningkatan ini terlihat dari nilai rata-rata kelas yang meningkat pada setiap siklusnya. Peningkatan tersebut dapat dilihat pada tabel berikut ini.

Tabel 9

Perbandingan Persentase Hasil Belajar Menulis Siswa Pada Siklus I dan Siklus II Perbandingan Hasil Belajar Menulis Siswa $\quad$ Peningkatan

Siklus I $\quad$ Siklus II $25 \%$

Dari tabel 9 di atas dapat dilihat adanya peningkatan sebesar $25 \%$ pada persentase ketuntasan tes hasil belajar menulis siswa, yakni dari 55\% pada siklus I meningkat menjadi $80 \%$ pada siklus II.

Berdasarkan uraian hasil penelitian beserta pembahasannya di atas, maka dapat disimpulkan bahwa pembelajaran Bahasa Indonesia dengan metode bermain jawaban dapat meningkatkan kemampuan menulis siswa.

\section{KESIMPULAN DAN SARAN \\ KESIMPULAN}

Dari pembahasan yang dijelaskan, maka dapat disimpulkan kegiatan menulis :

1. Siswa yang berdiskusi pada siklus 1 dengan persentase $37,05 \%$, sedangkan pada siklus II siswa yang bertanya berjumlah dengan persentase $70,00 \%$, sehingga dalam kategori baik.

2. Siswa yang menjawab pertanyaan pada siklus 1 dengan persentase $35,00 \%$, sedangkan pada siklus II siswa yang menjawab pertanyaan berjumlah dengan persentase $67,05 \%$, sehingga dalam kategori baik.

3. Siswa yang menanggapi pada siklus 1 dengan persentase $35,00 \%$, sedangkan pada siklus II siswa yang bertanya berjumlah dengan persentase $70,00 \%$, sehingga dalam kategori baik.

4. Siswa yang mengikuti diskusi dengan baik pada siklus 1 dengan persentase $42,05 \%$, sedangkan pada siklus II siswa yang mengikuti diskusi dengan baik berjumlah dengan persentase $77,05 \%$, sehingga dalam kategori baik

5. Siswa mendapatkan nilai hasil belajar menulis pada siklus I dengan persentase $55 \%$ sedangkan pada siklus II siswa yang mendapatkan hasil belajar menulis pada siklus II dengan persentase $80 \%$, sehingga dikatakan baik.

\section{SARAN}

Sehubungan dengan hasil penelitian yang diperoleh, maka peneliti memberikan saran dalam pelaksanaan pembelajaran dengan model bermain jawaban sebagai berikut:

1. Bagi siswa, agar meningkat kemampuan menulis siswa dalam proses pembelajaran dengan berpartisipasi menjawab pertanyaan, menanggapi pertanyaan dan berdiskusi karena dengan siswa aktif dalam berdiskusi maka akan menunjang semangat belajar.

2. Bagi guru yang melaksanakan pembelajaran dengan metode bermain jawaban dapat memberikan kesempatan bagi siswa dalam proses pembelajaran yaitu mengajukan pertanyaan, menjawab pertanyaan dan menyimpulkan pelajaran dan dijadikan salah satu alternative variasi dalam pelaksanaan pembelajaran.

3. Bagi peneliti yang mengambi ljudul ini sebaiknya dalam pembelajaran di variasikan dengan media gambar sehingga siswa tidak monoton atau jenuh dalam pembelajaran.

\section{DAFTAR PUSTAKA}

Arikunto, Suharsimi. 2006. Penelitian Tindakan Kelas. Jakarta: Bumi Aksara

Badan Standar Nasional Pendidikan (BNSP). 2006. Kurikulum Tingkat satuan (KTSP). Jakarta: BNSP Depdiknas

BSNP. 2007. Kurikulum Tingkat Satuan Pendidikan Sekolah Dasar. Jakarta: BSNP

Depdiknas. 2004. Pengembangan Kemampuan Membaca Cepat. Jakarta: Depdiknas

Dimiyati, Mudjiono. 2010. Penilaian Hasil Belajar. Jakarta

Hamalik, Oemar. 2001. Proses Belajar Mengajar. Jakarta: Bumi Aksara

Hisyam Zaini. 2005. Strategi Pembelajaran Aktif. Yogyakarta

Mulyasa,E. 2006. Kurikulum Yang Disempurnakan. Bandung: Remaja Rosdakarya

Resmini, Novi dan Dadan Juanda. 2007. Pendidikan Bahasa dan sastra Indonesia di Kelas Tinggi. Badung: UPI Press

Sanjaya, Wina. 2008. Kurikulum Pembelajaran. Jakarta: Prenada Media Grup 
Semi. M.Atar. 1990. Menulis Afektif. Padang. Angkasa Raya

Sudjana. 2009. Penilaian Hasil Proses Belajar Mengajar. Bandung: Remaja Rosdakarya

Suprijono, Agus 2013. Cooperative Learning.Yogyakarta:Pustaka Belajar

Susanto, Ahmad. 2014. Teori Belajar dan Pembelajaran di Sekolah Dasar. Jakarta: Kencana

Susmeri, Rita. 2008. Penilaian Proses Hasil Belajar. Bandung

Taniredja Tukiran. 2010. Penelitian Tindakan Kelas. Bandung: Alfabeta

Tarigan, Henry Guntur. 1986. Menulis Suatu Keterampilan Berbahasa. Bandung: Angkasa

Trianto. 2012. Model Pembelajaran Terpadu. Jakarta: Bumi Aksara

Warsono dan Hariyanto. 2013. Pembelajaran Aktif. Bandung: Remaja Rosdakarya Offset 